\title{
Effects of Eugenol and MS-222 Anaesthesia on Siberian Sturgeon Acipenser baerii Brandt
}

\author{
P. GOMULKA ${ }^{1}$, T. WLASOW${ }^{1}$, J. VELÍŠEK$^{2}$, Z. SVOBODOVÁ $^{2,3}$, E. CHMIELINSKA $^{1}$ \\ ${ }^{1}$ Faculty of Environmental Science and Fisheries, University of Warmia and Mazury Olsztyn, Poland \\ ${ }^{2}$ Research Institute of Fish Culture and Hydrobiology Vodňany, University of South Bohemia \\ ${ }^{3}$ University of Veterinary and Pharmaceutical Sciences Brno, Czech Republic
}

Received July 9, 2007

Accepted April 14, 2008

\begin{abstract}
Gomulka P., T. Wlasow, J.Velíšek, Z. Svobodová, E. Chmielinska: Effects of Eugenol and MS-222 Anaesthesia on Siberian Sturgeon Acipenser baerii Brandt. Acta Vet. Brno 2008, 77: 447-453.

The aim of the present study was to assess changes induced in the organism of Siberian sturgeon (Acipenser baerii) by eugenol and MS-222 anaesthesia on the basis of haematological indices, biochemical blood profile values and histological examinations. The haematological and biochemical indices were assessed in fish immediately and $24 \mathrm{~h}$ after anaesthesia. The results showed that despite no mortality occurred after anaesthesia in both $125 \mathrm{mg} \cdot \mathrm{l}^{-1}$ of MS-222 and $0.075 \mathrm{ml} \cdot 1^{-1}$ of eugenol, these chemical substances severely influenced the constituents of Siberian sturgeon blood and resulted in some histological changes in the gills and liver. Both eugenol and MS-222 anaesthesia caused erythrocyte swelling and haemolysis. The severe depletion of leukocyte number occurred $24 \mathrm{~h}$ after both eugenol and MS-222 anaesthesia (mainly due to depletion of lymphocyte, neutrophil segments and eosinophil fractions). Total protein, total globulin, triacylglycerol concentration and alanine aminotransferase activity in blood plasma was significantly elevated $(p<0.01)$ after both eugenol and MS-222 anaesthesia. The concentration of $\mathrm{Ca}^{2+}$, inorganic phosphate, $\mathrm{NH}_{3}$ and alkaline phosphatase activity were significantly decreased $(p<0.01)$ compared to control. No significant changes were noticed in the albumin and glucose concentrations and the activity of lactate dehydrogenase, aspartate aminotrasferase and creatinkinase. Results of the examinations suggest that the use of MS-222 $\left(125 \mathrm{mg} \cdot \mathrm{l}^{-1}\right)$ and eugenol $\left(0.075 \mathrm{ml}^{-1} \mathrm{l}^{-1}\right)$ does not cause irreversible damage in Siberian sturgeon.
\end{abstract}

Anaesthetics, blood, stress, Acipenseridae

Sturgeons are considered to be "living fossils" (Bemis et al. 1997). Primitive characteristics, such as a heterocercal tail and cartilaginous skeleton, have been maintained over approximately 100 - 200 million years despite major environmental changes (Baker et al. 2005; Asadi et al. 2006). Sturgeons have undergone multiple genome duplications during their evolution, which may account for their resistance to deleterious mutations, since there are probably several functional copies of every gene (Blacklidge and Bidwell 1993). Their primitive characteristics make sturgeons intriguing animals for study, since their biochemical haematological profile may differ substantially from the teleost profile.

All sturgeon species worldwide are covered under the provisions of CITES. Several species are considered threatened with extinction as a result of over-fishing, poaching, water pollution, damming and destruction of natural watercourses and habitats (Anonymous 2002). The culture of sturgeons is one of the on-growing aquaculture branch in Europe due to the need of active protection of natural populations and the high demand for caviar.

Usually the big size and sharp bony shields on the body surface make handling of sturgeon spawners difficult and dangerous for the operating personnel. The use of general anaesthetics is a common practise in sturgeon culture, especially during artificial 
propagation. Anaesthetics are also used during sorting, tagging, surgery and other stressinducing procedures.

Propiscin (Polish Inland Fisheries Institute; active substance is etomidate), administered on gills in the form of spray, is commonly and successfully used for immobilisation of sturgeons in Poland. However, preparations based on etomidate are not suitable for general anaesthesia because they probably do not bring analgesic effects and the recovery time is quite long (Brown 1988, own experience).

MS-222 (tricaine methanesulphonate) is probably the most frequently used anaesthetic world-wide in sturgeons (Wilga and Lauder 1999; Kirschbaum et al. 2000; Jodun et al. 2001; Jackson et al. 2002; Mohler 2003). It induces general anaesthesia in a short time and produces analgesia and good myorelaxation. Recovery time is usually short. However, the use of MS-222 is not recommended in some sturgeon species (pallid sturgeon Scaphirhynchus albus) due to adverse effects, including mortality (Wanner 2006).

In the last decade, many authors have published data addressing the anaesthetic properties of clove oil in fish. Clove oil is distilled from Eugenia aromatica or Eugenia caryophyllata. Its active ingredient, eugenol (4-allyl-2-methoxyphenol), makes up 70 to $90 \%$ by weight of clove oil. Clove oil also contains eugenol acetate $(>17 \%)$ (Sato and Burhanuddin 1995; Isaacs 1983; Briozzo et al. 1989; Keene et al. 1998). Despite the common use of anaesthetics in fish, there is little information about their influence on the sturgeon organism.

The aim of the present study was to assess the changes induced in the organism of Siberian sturgeon (Acipenser baerii) by eugenol and MS-222 on the basis of haematological indices, biochemical blood profile values and histological examinations.

\section{Materials and Methods}

Fish

Young sturgeons with the mean length of $253 \pm 75 \mathrm{~mm}$ (mean \pm SD) and mean weight of $94.90 \pm 55.23 \mathrm{~g}$ were used for the experiments. The fish were obtained from the Acipol Ltd. fish farm and were classified as Siberian sturgeon based on the morphological characteristics and farmer declaration. The fish were acclimated for 14 days to laboratory conditions. They were kept in 5001 fibreglass flow-through tanks equipped with automatic temperature regulation and artificial aeration and fed with commercial sturgeon pellets (AllerAqua 4515). The experiment was carried out at $17^{\circ} \mathrm{C} \pm 1{ }^{\circ} \mathrm{C}$ of water temperature. Water oxygen saturation was maintained above $80 \%$. Water $\mathrm{pH}$ was $7.8 \pm 0.2$ and hardness was $245 \mathrm{ppm}$.

\section{Anaesthetics}

MS-222 (tricaine methanesulphonate) and eugenol were delivered by Sigma-Aldrich Chemicals Ltd. The most adequate concentration for general anaesthesia in Siberian sturgeon was determined to be $125 \mathrm{mg} \cdot \mathrm{l}^{-1}$ for MS-222 and $0.075 \mathrm{ml} \cdot \mathrm{l}^{-1}$ for eugenol in a pre-experiment. The above concentrations meet the criteria proposed by Marking and Meyer (1985) most closely: induction of general anaesthesia in a time shorter than 3 min; recovery time shorter than $10 \mathrm{~min}$ and no mortality after $48 \mathrm{~h}$. The mean recovery time in case of eugenol was actually longer then $10 \mathrm{~min}\left(13{ }^{\prime} 26\right.$ ' $\left.\pm \mathrm{SD} 2{ }^{\prime} 52^{\prime \prime}\right)$.

Test procedure

The fish were divided into 5 groups $(\mathrm{N}=10)$. They were netted from the tank individually and immediately placed in 301 glass tanks filled with MS-222 or eugenol solution for a 10 min exposure. Blood samples for further analysis were collected immediately after exposure (MS-0 and Eug-0 groups, respectively) and $24 \mathrm{~h}$ after exposure (MS-24 and Eug-24 groups, respectively) (still bleeding fish were kept in 3001 flow-through glass tanks). Fish not exposed to anaesthetic solution constituted the control group. Control group sampling was done at the beginning of the test. All blood samples were taken by a syringe from caudal vessels within 2 min after netting fish out of the water. To stabilize blood samples, aqueous solution of heparin sodium salt at $0.01 \mathrm{ml}$ per $1 \mathrm{ml}$ blood was used (Svobodová et al. 1986). Fish feeding was stopped $24 \mathrm{~h}$ before experimental anaesthesia and fish were not fed during the entire test course.

\section{Haematological indices}

Procedures based on the unified methods for haematological examination of fish (Svobodová et al. 1986) were used to evaluate the haematological profile of sturgeon blood. Determined indices included the erythrocyte count $(\mathrm{Er})$, haemoglobin concentration $(\mathrm{Hb})$, haematocrit $(\mathrm{PCV})$, mean erythrocyte volume (MCV), mean corpuscular haemoglobin concentration $(\mathrm{MCHC})$, mean corpuscular haemoglobin content ( $\mathrm{MCH})$, leukocyte count (Leuko) and the differential leukocyte count (Leukogram). 
Histological examination

Samples of tissues for histological examination were taken from five control sturgeons at the start of the experiment, and from six fish from both MS-222 and eugenol anaesthetized groups $24 \mathrm{~h}$ after anaesthesia. In all cases, tissue samples were taken after blood sampling. Tissues were immediately fixed in Bouin's solution, drained and embedded in paraffin and stained with haematoxylin-eosin.

\section{Biochemical blood plasma profile}

Blood plasma was obtained by centrifuging blood samples in a cooled centrifuge $\left(4{ }^{\circ} \mathrm{C}, 837 \times g\right)$. Biochemical indices determined in blood plasma included glucose (GLU), total proteins (TP), albumins (ALB), total globulins $(\mathrm{GLOB})$, triacylglycerols (TAG), ammonia $\left(\mathrm{NH}_{3}\right)$, lactate dehydrogenase (LDH), aspartate aminotransferase $(\mathrm{AST})$, alanine aminotransferase (ALT), alkaline phosphatase (ALP), creatine kinase (CK), calcium $\left(\mathrm{Ca}^{2+}\right.$ and inorganic phosphate (PHOS).

For plasma biochemical analysis, VETTEST 8008 analyser (IDEXX Laboratories Inc., USA; Medisoft Co.) was used. The apparatus is based upon dry chemical technology and colorimetric reaction. Sample analysis was carried out on selective testing discs (Multi-layer film slides, Kodak) by means of laser reading of the bar codes. Detection limits of the methods were as follows: GLU $\left(0.01 \mathrm{mmol} \cdot \mathrm{l}^{-1}\right), \mathrm{TP}\left(1.0 \mathrm{~g} \cdot \mathrm{l}^{-1}\right), \operatorname{ALB}\left(1.0 \mathrm{~g} \cdot \mathrm{l}^{-1}\right), \mathrm{GLOB}(1.0$ $\left.\mathrm{g} \cdot \mathrm{l}^{-1}\right)$, TAG $\left(0.01 \mathrm{mmol} \cdot \mathrm{l}^{-1}\right), \mathrm{NH}_{3}(1.0 \mu \mathrm{mol}), \mathrm{LDH}\left(0.0167 \mu \mathrm{kat} \cdot \mathrm{l}^{-1}\right), \operatorname{AST}\left(0.0835 \mu \mathrm{kat} \cdot \mathrm{l}^{-1}\right), \operatorname{ALT}\left(0.0835 \mu \mathrm{kat} \cdot \mathrm{l}^{-1}\right.$ ), $\operatorname{ALP}\left(0.0167 \mu \mathrm{kat} \cdot \mathrm{l}^{-1}\right), \mathrm{CK}\left(0.0167 \cdot \mu \mathrm{kat} \cdot \mathrm{l}^{-1}\right), \mathrm{Ca}^{2+}\left(0.01 \mathrm{mmol} \cdot \mathrm{l}^{-1}\right)$ and PHOS $\left(0.01 \mathrm{mmol} \cdot \mathrm{l}^{-1}\right)$.

Statistical analysis

Results of the experiment were tested by non-parametric variance analysis (Kruskall-Wallis) and MannWhitney test using the Toxicologist 1.0 software (The Euro-Mediterranean Centre on Marine Contamination Hazards 1989).

\section{Results}

\section{Haematological indices}

Results of haematological examinations are shown in Table 1. No statistically important differences were noticed in mean blood haemoglobin concentration. Both eugenol and MS-222 caused a severe decrease of leukocyte count $24 \mathrm{~h}$ after exposure. The erythrocyte count was significantly lower $(p<0.01)$ in the eugenol group immediately after anaesthesia compared to all the other groups. The mean PCV value was higher $(p<0.05)$ in the MS-0 group compared to the control; however, this value was not significantly different compared to other groups. In the Eug-0 group, PCV was slightly higher compared to the Eug-24 group $(p<0.05)$. MCV and MCH were significantly higher $(p<0.01)$ in both Eug-0 and MS-0 groups compared to other groups. The mean MCHC value in MS-0 group was significantly much higher than in all other groups $(p<0.01)$.

Table 1. Effects of eugenol and MS-222 anaesthesia on haematological indices in Siberian sturgeon

\begin{tabular}{|c|c|c|c|c|c|}
\hline \multirow[b]{2}{*}{ Indices } & \multirow[b]{2}{*}{ Control } & \multicolumn{2}{|c|}{ Eugenol } & \multicolumn{2}{|c|}{ MS-222 } \\
\hline & & $\begin{array}{c}\text { Immediately } \\
\text { after anaesthesia }\end{array}$ & $\begin{array}{c}24 \mathrm{~h} \text { after } \\
\text { anaesthesia }\end{array}$ & $\begin{array}{c}\text { Immediately } \\
\text { after anaesthesia }\end{array}$ & $\begin{array}{l}24 \mathrm{~h} \text { after } \\
\text { anaesthesia }\end{array}$ \\
\hline $\operatorname{Er}(\mathrm{T} / \mathrm{L})$ & $0.32 \pm 0.08$ & $0.19 \pm 0.03^{* a}$ & $0.32 \pm 0.09^{b}$ & $0.26 \pm 0.04^{\mathrm{c}}$ & $0.39 \pm 0.10^{\mathrm{b}}$ \\
\hline Leuko (G/L) & $6.08 \pm 2.51$ & $4.99 \pm 1.46^{\mathrm{a}}$ & $1.68 \pm 0.59 * b$ & $5.87 \pm 3.57^{\mathrm{a}}$ & $2.68 \pm 1.47^{* b}$ \\
\hline $\mathrm{Hb}(\mathrm{g} / \mathrm{L})$ & $28.16 \pm 6.74$ & $34.76 \pm 10.98^{\mathrm{a}}$ & $29.56 \pm 7.87^{\mathrm{a}}$ & $32.92 \pm 13.88^{\mathrm{a}}$ & $33.28 \pm 6.54^{\mathrm{a}}$ \\
\hline $\mathrm{PCV}$ & $0.19 \pm 0.03$ & $0.22 \pm 0.03^{\mathrm{a}}$ & $0.18 \pm 0.03^{b}$ & $0.24 \pm 0.04^{* a}$ & $0.21 \pm 0.04^{\mathrm{ab}}$ \\
\hline MCV (fl) & $641 \pm 207$ & $1374 \pm 269 * a$ & $605 \pm 156^{b}$ & $1194 \pm 544^{* a}$ & $550 \pm 133^{b}$ \\
\hline $\mathrm{MCH}(\mathrm{pg})$ & $92.8 \pm 37.8$ & $184.3 \pm 69.6^{* \mathrm{a}}$ & $96.9 \pm 32.3^{b}$ & $149.4 \pm 48.1^{* a}$ & $87.1 \pm 17.7^{b}$ \\
\hline $\mathrm{MCHC}(\mathrm{g} / \mathrm{L})$ & $146.0 \pm 2.59$ & $153.0 \pm 6.00^{\mathrm{a}}$ & $158.0 \pm 2.86^{\mathrm{a}}$ & $665.0 \pm 17.68^{* b}$ & $162.0 \pm 1.93^{\mathrm{a}}$ \\
\hline
\end{tabular}

values marked with * are statistically different compared to control values marked with different letter index are statistically different

Table 2 shows the results of differential leukocyte count in experimental and control sturgeons. The number of lymphocytes was significantly decreased $(p<0.01)$ in both eugenol and MS-222 group after $24 \mathrm{~h}$ compared to control and respective groups immediately after anaesthesia. The number of neutrophil segments was significantly lower 
Table 2. Effects of eugenol and MS-222 anaesthesia on the differential leukocyte count in Siberian sturgeon

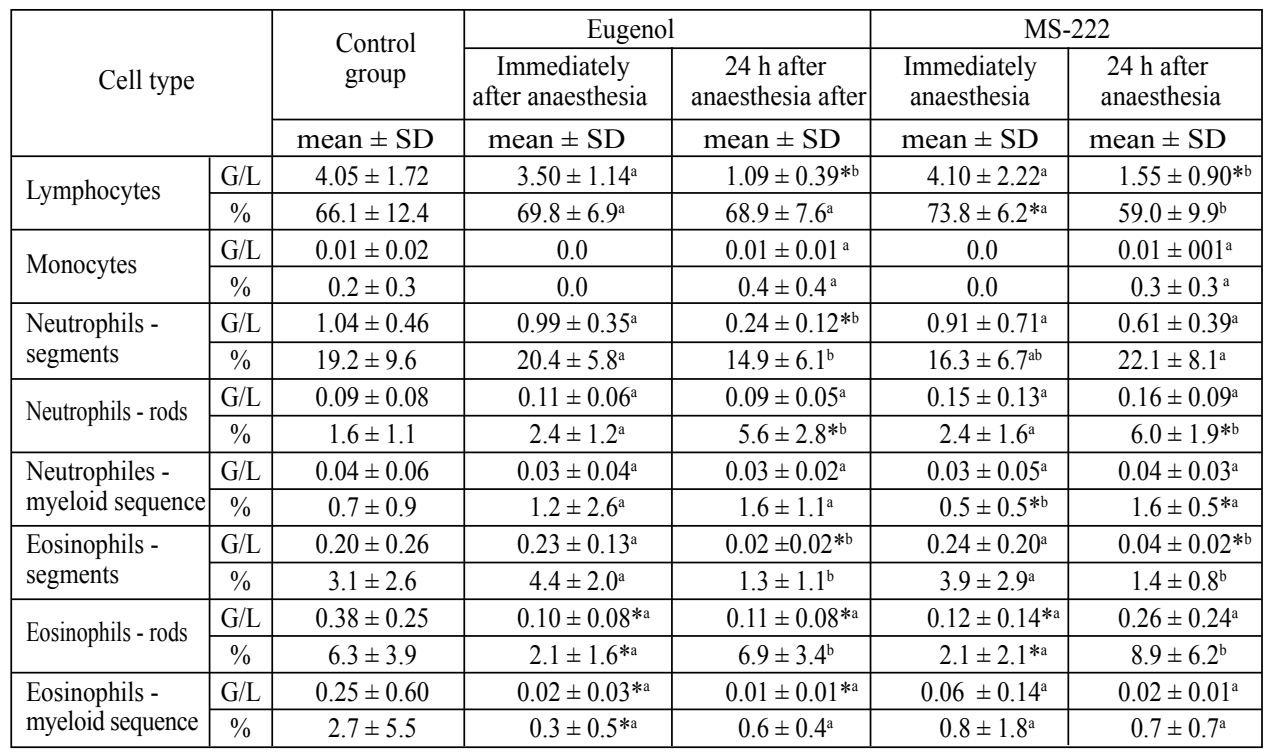

values marked with * are statistically different compared to control values marked with different letter index are statistically different

$(p<0.01)$ in the Eug-24 group compared to both control and Eug-0 group. There was no significant difference between the groups in the number of both the neutrophil rods and the neutrophil myeloid sequence. Similarly to lymphocyte numbers, the number of eosinophil segments was lower $(p<0.01)$ in both " 24 " groups compared to control and " 0 " groups. The number of eosinophil rods was significantly lower $(p<0.01)$ in Eug-0 and Eug-24 groups compared to control. The number of eosinophil myeloid sequence was significantly decreased $(p<0.05)$ in both Eug-0 and Eug-24 groups compared to control.

Biochemical blood plasma profile

The results are shown in Table 3. Significant increase in TP and GLOB occurred in both the eugenol groups and MS- 0 group compared to control $(p<0.01)$. All the experimental groups revealed a significant decrease in $\mathrm{Ca}$, PHOS and $\mathrm{NH}_{3}$ concentrations in blood plasma $(p<0.05)$ and a significant increase in TAG concentration $(p<0.05)$ compared to control. The activity of ALT was significantly increased in all the experimental groups $(p<0.05)$ and the activity of ALP was significantly decreased in all groups compared to control. No significant differences were noticed between control and experimental groups in ALB, GLU, LDH, AST and CK indices. No significant differences were noticed between respective " 0 " and "24" groups for both eugenol and MS-222 anesthetized sturgeons.

Histopathological findings

Evident congestion of sinusoid capillaries was observed in the liver of Siberian sturgeons $24 \mathrm{~h}$ after MS-222 anaesthesia (Plate XIII, Fig. $1 \mathrm{~A}$ ). Sections taken from gills of fish treated with MS-222 showed a swelling of primary and secondary lamellae (Plate XIII, Figs 2B, $2 \mathrm{E})$. The spaces between secondary lamellae were decreased due to hypertrophy of the epithelial cells. Lamellar hypertrophy was also observed in sturgeons treated with eugenol, however, these lesions were less intensive (Plate XIII, Figs 2C, 2D). Slight congestion of capillaries and cell necrosis occurred rarely in both experimental groups. 
Table 3. Effects of eugenol and MS-222 anaesthesia on the biochemical blood indices in Siberian sturgeon

\begin{tabular}{|c|c|c|c|c|c|}
\hline \multirow[b]{2}{*}{ Indices } & \multirow[b]{2}{*}{ Control } & \multicolumn{2}{|c|}{ Eugenol } & \multicolumn{2}{|c|}{ MS-222 } \\
\hline & & $\begin{array}{c}\text { Immediately } \\
\text { after anaesthesia }\end{array}$ & $\begin{array}{c}24 \mathrm{~h} \text { after } \\
\text { anaesthesia }\end{array}$ & $\begin{array}{c}\text { Immediately } \\
\text { after anaesthesia }\end{array}$ & $\begin{array}{l}24 \mathrm{~h} \text { after } \\
\text { anaesthesia }\end{array}$ \\
\hline $\mathrm{TP}\left(\mathrm{g} \cdot \mathrm{l}^{-1}\right)$ & $9.67 \pm 1.97$ & $12.12 \pm 4.39 *$ & $13.33 \pm 2.55^{*}$ & $12.64 \pm 2.84 *$ & $10.57 \pm 1.72$ \\
\hline $\operatorname{GLOB}\left(g \cdot 1^{-1}\right)$ & $8.83 \pm 2.14$ & $11.37 \pm 4.53^{*}$ & $12.56 \pm 2.92 *$ & $12.00 \pm 3.03 *$ & $9.86 \pm 1.95$ \\
\hline $\operatorname{ALB}\left(g \cdot l^{-1}\right)$ & $0.83 \pm 0.41$ & $0.75 \pm 0.46$ & $0.78 \pm 0.441$ & $0.82 \pm 0.40$ & $0.71 \pm 0.49$ \\
\hline GLU $\left(\mathrm{mmol} \cdot \mathrm{l}^{-1}\right)$ & $1.73 \pm 0.27$ & $1.73 \pm 0.38$ & $1.85 \pm 0.134$ & $1.83 \pm 0.38$ & $1.58 \pm 0.26$ \\
\hline TAG $\left(\mathrm{mmol} \cdot \mathrm{l}^{-1}\right)$ & $1.02 \pm 0.10$ & $1.76 \pm 0.99 *$ & $1.43 \pm 0.05^{*}$ & $1.67 \pm 0.28 *$ & $1.36 \pm 0.19^{*}$ \\
\hline $\mathrm{Ca}^{2+}\left(\mathrm{mmol}^{-1}{ }^{-1}\right)$ & $1.89 \pm 0.22$ & $1.47 \pm 0.11^{*}$ & $1.44 \pm 0.11^{*}$ & $1.47 \pm 0.17 *$ & $1.35 \pm 0.18^{*}$ \\
\hline PHOS $\left(\mathrm{mmol}^{-1}{ }^{-1}\right)$ & $2.90 \pm 0.10$ & $2.16 \pm 0.15^{*}$ & $1.95 \pm 0.56^{*}$ & $2.27 \pm 0.22 *$ & $2.24 \pm 0.13^{*}$ \\
\hline $\mathrm{NH}_{3}\left(\mu \mathrm{mol} \cdot l^{-1}\right)$ & $584.0 \pm 51.3$ & $525.1 \pm 32.7^{*}$ & $520.7 \pm 70.1^{*}$ & $534.9 \pm 28.0^{*}$ & $504.6 \pm 88.5^{*}$ \\
\hline LDH $\left(\mu \mathrm{kat}^{-1} \mathrm{l}^{-1}\right)$ & $18.02 \pm 0.26$ & $17.98 \pm 0.45$ & $18.21 \pm 0.73$ & $17.91 \pm 0.60$ & $17.69 \pm 0.74$ \\
\hline $\operatorname{AST}\left(\mu \mathrm{kat} \cdot \mathrm{l}^{-1}\right)$ & $2.42 \pm 0.33$ & $2.73 \pm 0.45$ & $2.56 \pm 0.18$ & $2.77 \pm 0.26$ & $2.61 \pm 1.32$ \\
\hline $\operatorname{ALT}\left(\mu \mathrm{kat} \cdot \mathrm{l}^{-1}\right)$ & $0.10 \pm 0.01$ & $0.19 \pm 0.04 *$ & $0.18 \pm 0.04 *$ & $0.18 \pm 0.04^{*}$ & $0.18 \pm 0.04 *$ \\
\hline $\operatorname{ALP}\left(\mu \mathrm{kat} \cdot 1^{-1}\right)$ & $1.01 \pm 0.12$ & $0.67 \pm 0.08 *$ & $0.66 \pm 0.10^{*}$ & $0.66 \pm 0.24 *$ & $0.66 \pm 0.11^{*}$ \\
\hline $\mathrm{CK}\left(\mu \mathrm{kat} \cdot \cdot^{-1}\right)$ & $15.21 \pm 0.48$ & $15.17 \pm 0.48$ & $15.33 \pm 0.59$ & $15.07 \pm 0.18$ & $15.23 \pm 0.61$ \\
\hline
\end{tabular}

Values marked with * are statistically different compared to control; no statistical difference was found between experimental groups

\section{Discussion}

Careful and controlled MS-222 anaesthesia is thought to be useful in haematological examinations due to lack of a significant effect on the haematological indices in fish (Bourne 1984). No changes in haematological indices were noticed in teleost fish following eugenol anaesthesia (Velíšek et al. 2005, 2006). However, our results seem to indicate a severe impact of both eugenol and MS-222 on haematological indices in Siberian sturgeon. Anaesthesia probably resulted in erythrocyte swelling (high increase of MCV immediately after anaesthesia), followed by an increase of the PCV value in the MS-0 group. The PCV value was not increased in eugenol-anaesthetised sturgeons. However, the number of erythrocytes was severely depleted, probably due to haemolysis. The high increase of $\mathrm{MCH}$ in both groups immediately after anaesthesia is probably an apparent phenomenon, as the method used for measuring haemoglobin concentration measures total blood volume haemoglobin, not specifically erythrocyte haemoglobin. The $\mathrm{MCH}$ value is virtually shifted during calculations in case of haemolysis. We concluded that both eugenol and MS-222 caused the swelling and destruction of erythrocytes. Changes were less severe in case of MS-222 and could be compensated by an erythrocyte release from blood storage organs, which resulted in lack of significant changes in the erythrocyte number and the significant increase of $\mathrm{PCV}, \mathrm{MCH}$ and $\mathrm{MCHC}$ value in this group (Table 1). The TP and GLOB shift probably resulted from the erythrocyte destruction. All the above changes were reversible and returned to normal after $24 \mathrm{~h}$, except for TP and Glob in the eugenol anaesthetized group. It seems that repeated eugenol or MS-222 anaesthesia could result in anaemia in Siberian sturgeon.

Hatting (1977) has showed that MS-222 produces an increase of haematocrit value and haemolysis in some cyprinid fish in the in vitro experiment. Smit et al. (1979) stated that MS-222 affects erythrocyte osmotic fragility. Ferreira et al. (1981) attributed high erythrocyte osmotic fragility following benzocaine and MS-222 anaesthesia to low blood plasma $\mathrm{pH}$ induced during anaesthesia.

The leukocyte number was severely depleted $24 \mathrm{~h}$ after both MS-222 and eugenol anaesthesia, mainly due to the depletion of lymphocytes, neutrophil segments and eosinophil fractions (Tables 1 and 2). According to Angelidis et al. (1987) lymphopaenia 
is one of the results of stress reaction in fish. However, another stress indicator, GLU, was not affected in our experiment. Decreased PHOS and $\mathrm{NH}_{3}$ concentration (Table 3) seems to be the result of a decreased metabolic rate. Baker et al. (2005) found no changes in haemoglobin, haematocrit and MCHC following severe experimental hypoxia in both Atlantic and shortnose sturgeons. The plasma cortisol and plasma glucose and lactate were elevated; however, the extent of this elevation was lower than in teleost fish. Beyea et al. (2006) concluded that shortnose sturgeon respond to external stress to a negligible extent. They speculated that sturgeon may be able to mobilize energy stores using alternative to corticosteroid stress response pathway. They suggested that hyperlipidaemia initiated through the adrenaline release from chromaffin cells (Matty 1985) may be such alternative pathway. This is in agreement with our results; both MS-222 and eugenol anaesthetized Siberian sturgeons showed elevated level of TAG immediately and $24 \mathrm{~h}$ after anaesthesia. Our experiment showed that anaesthesia with both $125 \mathrm{mg} \cdot \mathrm{l}^{-1}$ of MS-222 and $0.075 \mathrm{ml} \cdot \mathrm{l}^{-1}$ of eugenol severely impact the constituents of Siberian sturgeon blood and result in some histological changes in the gills and liver.

\section{Vliv anestetik eugenolu a MS-222 na jesetera sibiřského (Acipenser baerii Brandt)}

Cílem studie bylo posoudit změny v organismu jesetera sibiřského (Acipenser baerii) po anestézii eugenolem a MS-222 na základě hematologického, biochemického a histologického vyšetření. Hematologické a biochemické vyšetření bylo provedeno u ryb ihned a 24 h po anestézii. Výsledky experimentu ukázaly, že navzdory nulové mortalitě po anestézii oběma látkami MS-222 $\left(125 \mathrm{mg} \cdot \mathrm{l}^{-1}\right)$ a eugenolu $\left(0,075 \mathrm{ml} \cdot \mathrm{l}^{-1}\right)$, měla anestézie vliv na hematologické a biochemické ukazatele jesetera sibiřského a způsobila histopatologické změny na žábrech a játrech. Výsledky ukázaly, že anestézie eugenolem a MS-222 vyvolala zvětšení objemu erytrocytů a hemolýzu. 24 h po anestézii oběma anestetiky došlo ke snížení počtu leukocytů (a to hlavně v důsledku snížení počtu lymfocytů, neutrofilních segmentů a eosinofilů). Koncentrace celkových bílkovin, celkových globulinů, triacylglycerolů, a aktivita alanin aminotransferázy v krevní plazmě byla signifikantně zvýšena $(p<0,01)$ po anestézii eugenolem a MS-222. Koncentrace $\mathrm{Ca}^{2+}$, anorganického fosfátu, amoniaku, a aktivita alkalické fosfatázy byla signifikantně snížena $(p<0,01)$ oproti kontrole. Nebyly zaznamenané významné změny u koncentrace albuminu, glukózy a aktivity laktát dehydrogenázy, aspartát aminotrasferázy a kreatinkinázy. Výsledky ukázaly, že MS-222 $\left(125 \mathrm{mg} \cdot \mathrm{l}^{-1}\right)$ a eugenol $\left(0,075 \mathrm{ml} \cdot \mathrm{l}^{-1}\right)$ jsou bezpečné pro jesetera sibiřského.

\section{Acknowledgements}

This work was supported by the Ministry of Education, Youth and Sports of the Czech Republic (Project No. MSM 6007665809) and by the Grant number 0804-0809 of the University of Warmia and Mazury in Olsztyn, Poland, and by the Ministry of Agriculture Project NAZV QF3029 Harmonization with the EU in applying pharmacovigilance principles in aquaculture in the Czech Republic. The authors appreciate very much the help provided by Elżbieta Ziomek.

\section{References}

ANGELIDIS P, BAUDIN-LAURENCIN F, YOUINOU P 1987: Stress in rainbow trout, Salmo gairdneri: effects upon phagocyte chemiluminescence, circulating leucocytes and susceptibility to Aeromonas salmonicida. J Fish Biol 31: 113-122

ANONYMOUS 2002: WWF Factsheet: $12^{\text {th }}$ meeting of the conference of the parties to CITES. Santiago, 3-15 November 2002 (www.panda.org/species/CITES)

ASADI F, MASOUDIFARD M, VAJHI A, LEE K, POURKABIR M, KHAZRAEINIA P 2006: Serum biochemical parameters of Acipenser persicus. Fish Physiol Biochem 32: 43-47

BAKER DW, WOOD AM, KIEFFER JD 2005: Juvenile Atlantic and shortnose sturgeons (Family: Acipenseridae) have different haematological responses to acute environmental hypoxia. Physiol Biochem Zool 78: 916-925 
BAKER DW, WOOD AM, LITVAK MK, KIEFFER JD 2005: Haematology of juvenile Acipenser oxyrinchus and Acipenser brevirostrum at rest following forced activity. J Fish Biol 66: 208-221

BEMIS WE, FINDEIS EK, GRANDE L 1997: An overview of Acipenseriformes. Environ Biol Fishes 48: $25-71$

BEYEA MM, BENFEY TJ, KIEFFER JD 2006: Haematology and stress physiology of juvenile diploid and triploid shortnose sturgeon (Acipenser brevirostrum). Fish Physiol Biochem 31: 303-313

BLACKLIDGE KH, BIDWELL CA 1993: Three ploidy levels indicated by genome quantification in Acipenseriformes of North America. J Hered 84: 427-430

BOURNE PK 1984: The use of MS-222 (tricaine methanesulphonate) as an anaesthetic for routine blood sampling in three species of marine teleosts. Aquaculture 36: 313-321

BRIOZZO J, NÚÑEZ L, CHIRIFE J, HERSZAGE L, D’AQUINO M 1989: Antimicrobial activity of clove oil dispersed in a concentrated sugar solution. J Appl Bacteriol 66: 69-75

BROWN LA 1988: Anaesthesia in fish. Vet Clin North Am Small Anim Pract 18: 317

FERREIRA JT, SMIT GL, SCHOONBEE HJ 1981: The effect of anaesthetic benzocaine hydrochloride on red cell fragility in Cyprinus carpio. J Fish Biol 18: 123-126

HATTING J 1977: The effect of tricaine methanesulphonate (MS-222) on the microhaematocrit of fish blood. J Fish Biol 10: 453-455

ISAACS G 1983: Permanent local anaesthesia and anhydrosis after clove oil spillage. Lancet 1: 882-883

JACKSON JR, VAN DEVALK AJ, BROOKING TE, VAN KEEKEN OA, RUDSTAM LG 2002: Growth and feeding dynamics of lake sturgeon, Acipenser fulvescens, in Oneida Lake, New York: results from the first five years of a restoration program. J Appl Ichthyol 18: 439-443

JODUN W, MILLARD M, MOHLER J, BARTON T 2001: Comparative efficacy of three potential anaesthetics applicable to Atlantic sturgeon Acipenser oxyrinchus and their physiological consequences. Study number: LM-00-06. In: Annual report of biological activities. U.S. Fish and Wildlife Service. Northeast Fishery Center, Lamar, USA.

KEENE JL, NOAKES DLG, MOCCIA RD, SOTO CG 1998: The efficacy of clove oil as an anaesthetic for rainbow trout, Oncorhynchus mykiss (Walbaum). Aquac Res 29: 89-101

KIRSCHBAUM F, GESSNER J, WILLIOT P 2000: Restoration of Acipenser sturio L. 1758 in Germany: Growth characteristics of juvenile fish reared under experimental indoor conditions. Biol Inst Esp Oceanogr 16:157-165

MARKING LL, MEYER FP 1985: Are better anaesthetics needed in fisheries? Fisheries 10: 2-5

MATTY AJ 1985: The 'adrenal' and the kidney hormones. In MATTY AJ (Ed.): Fish endocrinology. Timber Press, Portland, USA, pp. 112-137

MOHLER JW, 2003: Culture manual for the Atlantic sturgeon Acipenser oxyrinchus. A Region 5 U.S. Fish \& Wildlife Service publication. 300 Westgate Center Drive, Hadley, Massachusetts, p. 66

SATO CG, BURHANUDDIN S 1995: Clove oil as a fish anaesthetic for measuring length and weight of rabbitfish (Siganus lineatus). Aquaculture 136: 149-152

SMIT GL, HATTING J, BURGER AP 1979: Haematological assessment of the effects of anaesthetic MS-222 in natural and neutralized form in three freshwater fish species: haemoglobin electrophoresis, ATP levels and corpuscular fragility curves. J Fish Biol 15: 633-645

SVOBODOVÁ Z, PRAVDA D, PALÁČKOVÁ J 1986: Unified methods of haematological examination of fish. Research Institute of Fish Culture and Hydrobiology, Vodňany. Methods 20: 31

VELÍŠEK J, SVOBODOVÁ Z, PIÁČKOVÁ V 2005: Effects of clove oil anaesthesia on rainbow trout (Oncorhynchus mykiss). Acta Vet Brno 74: 139-146

VELÍŠEK J, WLASOW T, GOMULKA P, SVOBODOVÁ Z, NOVOTNÝ L, ZIOMEK E 2006: Effects of clove oil anaesthesia on European catfish (Silurus glanis L.). Acta Vet Brno 75: 99-106

WANNER GA 2006: Evaluation of a gastric lavage method on juvenile pallid sturgeon. North Am J Fish Manage 26: $587-591$

WILGA CD, LAUDER GV 1999: Locomotion in sturgeon: function of the pectoral fins. J Exp Biol 202: 2413-2432 
Plate XIII

Gomulka P. et al.: Effect of ... pp. 447-453
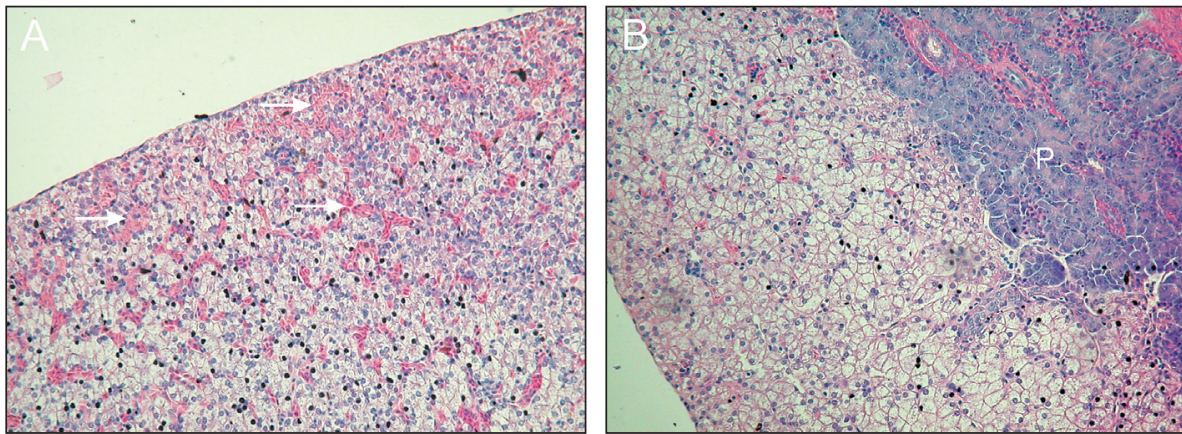

Fig. 1. Section through the liver of Siberian sturgeon: A - $24 \mathrm{~h}$ after anaesthesia with MS 222; the congestion of sinusoid capillaries (arrows), B - control fish; $\mathrm{p}$ - pancreas [× 100; H \& E].
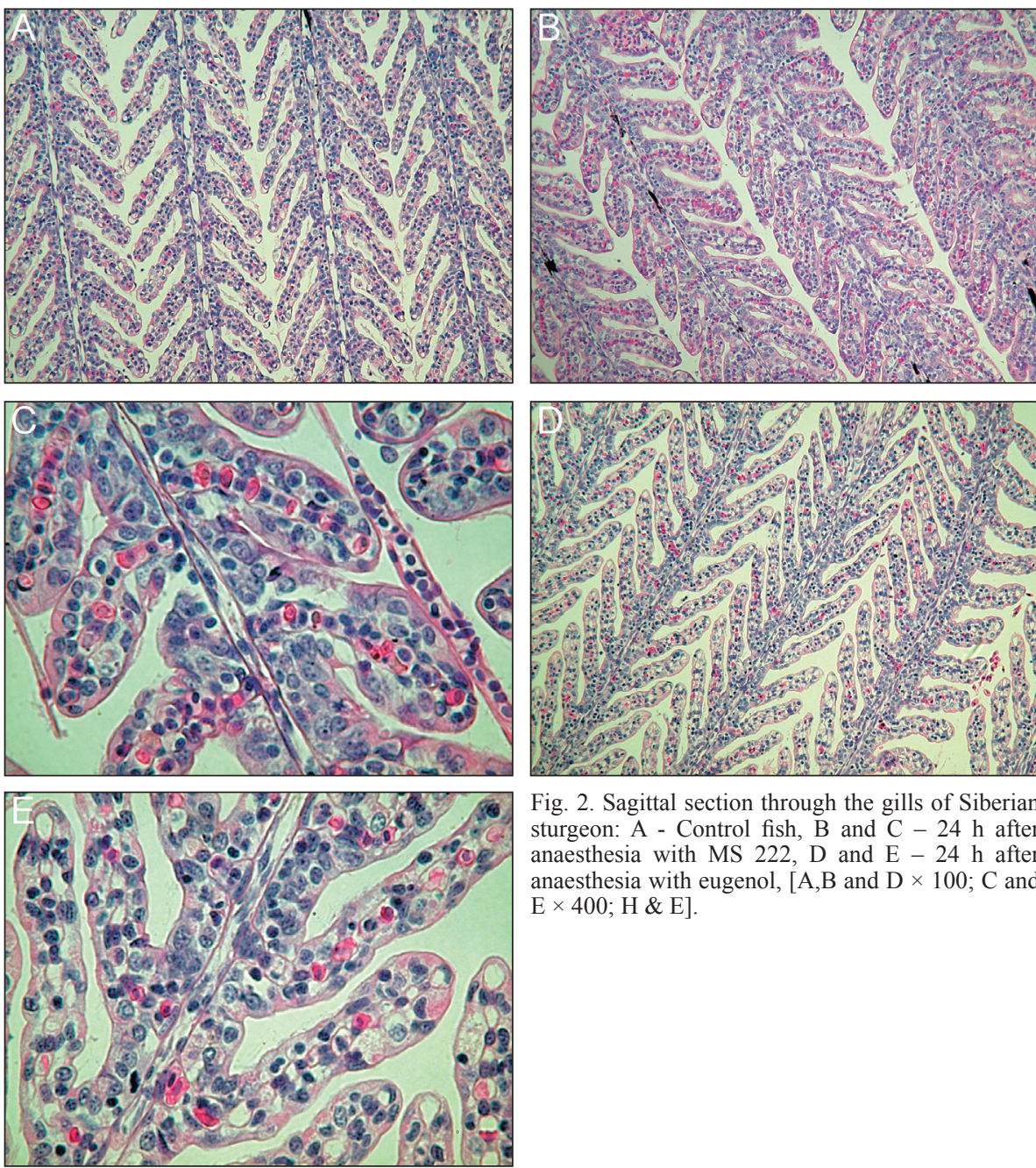

Fig. 2. Sagittal section through the gills of Siberian sturgeon: A - Control fish, B and C - $24 \mathrm{~h}$ after anaesthesia with MS 222, D and E $-24 \mathrm{~h}$ after anaesthesia with eugenol, [A,B and $\mathrm{D} \times 100 ; \mathrm{C}$ and E $\times 400 ; \mathrm{H} \& \mathrm{E}]$. 